\title{
Nutrient Analysis of Tender Jackfruit (Artocarpus heterophyllus) flour and its Incorporation in Breakfast Recipes for Diabetics
}

\author{
Christy Paul ${ }^{1}$ and Betty Rani Isaac ${ }^{2 *}$ \\ 'Student, Department of Home Science, St. Teresa's College, Ernakulam - 682011, Kerala, India; \\ christypallippadan@gmail.com \\ ${ }^{2 *}$ Associate Professor and Head, Department of Home Science, St. Teresa's College, Ernakulam - 682011, Kerala, \\ India; bettyranijose@yahoo.com
}

\begin{abstract}
Jackfruit is an important underutilized fruit in Kerala and often called the poor man's fruit because of its affordability and availability in large quantities during the season. The rich bioactive profile of jackfruit makes it a highly nutritious and desirable fruit crop. The value added products from Jackfruit namely tender jackfruit flour is now being manufactured in Kerala with minimal processing so that they can be added in recipes. Generally tender jackfruit is known to be good food for diabetic patients. Study was designed to analyse the nutrient content of tender jackfruit flour. An attempt was made to develop breakfast recipes incorporated with tender jackfruit flour for diabetic patients. The nutrient composition of tender jackfruit flour was analyzed using standardized procedures. Survey was conducted to identify the types of breakfast items which were frequently consumed by diabetic patients. Sixty diabetic patients were selected equally from urban, rural and coastal areas of Ernakulam District in Kerala to conduct the survey. The tools used to collect data in the present study were interview schedule and questionnaire. A total of eight breakfast recipes commonly used by the subjects were selected. To the basic recipe, incorporation of jackfruit flour was done until a good product was obtained. Hundred percent tender jackfruit flour could be used in Chapati, Puttu and Idiyappam. All the developed breakfast items (Puttu, Dosa, Appam, Chapatis, Porridge, Idiyappam, Upma, Idli) were evaluated for their acceptability by a semi trained panel of ten judges.
\end{abstract}

Keywords: Breakfast Recipes, Nutrient Content, Sensory Evaluation, Tender Jack Fruit Flour

\section{Introduction}

Jackfruit is a popular fruit in India. Though jackfruit is not abundantly available in all parts of India, it is widely grown in Kerala. Jackfruit (Artocarpus heterophyllus Lam.) trees belong to the family Moraceae. The primary economic product of jackfruit is the fruit, used both when immature and when mature. The fresh de-seeded sweet pulp of the fruit are consumed as such by people and cannot be stored for long time due to its perishability, as a result huge post-harvest losses (30-35\%) occur during the peak season. Jackfruit is widely used in culinary preparations. Ripe fruit and the jackfruit seeds which have unique flavor are widely consumed as a dessert or as an ingredient in Asian culinary preparations. Mature jackfruit are cooked as vegetables and used in curries or salads. Advances in food processing technologies further expanded the possibilities of value added products from jackfruit ${ }^{1}$. One of the important value added products from Jackfruit, is tender jackfruit flour which is now being manufactured in Kerala with minimal processing so that they can be incorporated in to recipes.

Jackfruit is a power house of important nutrients. The flesh of jackfruit is rich in beta carotene, calcium

*Author for correspondence 
and riboflavin while the seeds are rich in phosphrous, calcium, iron, thiamine and vitamin $\mathrm{C}^{1}$. Jackfruit contains phytonutrients: lignans, isoflavones, and saponins that have health benefits that are wide ranging. These phytonutrients have anticancer, antihypertensive, antiulcer and antiaging properties.

Extract from the seeds are useful in the treatment of diarrhoea and dysentery. Roasted seeds are believed to possess aphrodisiac properties. The leaves are believed to be effective in the treatment of asthma, ringworm infestation, diabetes and gall stones ${ }^{2}$.

Jackfruit meal has known to have a low Glycemic Index (GI). The low GI could be due to the collective contributions from dietary fiber, slowly available glucose and un-gelatinised (intact) starch granules in the seeds ${ }^{3}$. Because of the high fibre content and low glycemic load, jackfruit is good food for diabetic patients. There is not much studies done on the nutrient composition of tender jackfruit.

There are ample opportunities for value addition of jack fruit in all stages of maturity right from immature to well ripened stage. It is in this background the present study "Nutrient Analysis of tender jackfruit flour and its incorporation in breakfast recipes for diabetics" was undertaken to investigate the nutrient composition of tender jackfruit flour and the possibility of incorporating it in to the breakfast recipes with a view to provide useful information for its effective utilization.

\section{Materials and Methods}

\subsection{Selection of Sample (Artocarpus heterophyllus)}

The sample selected for the study was tender jackfruit flour. Previous study ${ }^{4}$ has suggested that the tender jackfruit extract has hypoglycemic potential.

\subsection{Collection of the Jackfruit Flour}

Due to the problem of seasonal availability, for the present study, tender jackfruit flour (Artocarpus heterophyllus) was procured from the Ex-Service Men's Society, Vettilapara, near Athirapilly waterfall, of Thrissur District in Kerala, India. In this unit, they produce jackfruit powder, tender jackfruit flour and jack seed powder for product development. They procure jackfruit (Figure 1) mainly from local areas. The cost of tender jackfruit powder is rupees 450 per $\mathrm{kg}$.

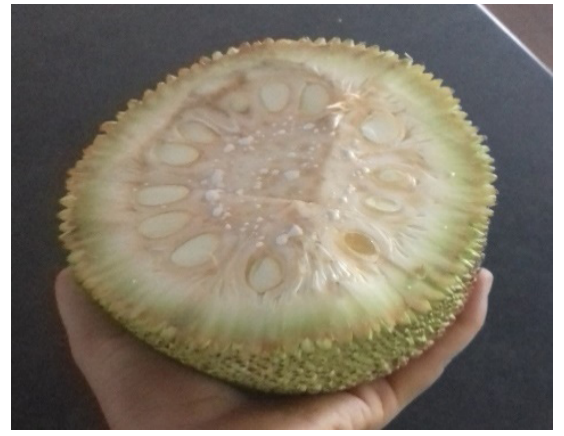

Figure 1. Tender Jackfruit.

\subsection{Processing of the Tender Jackfruit into flour}

Food processing is set of methods and techniques used to transform raw ingredients into food or to transform food into other forms for consumption either in home or by the food processing industry. To increase the shelf life and to make it ideal for incorporation into recipes, tender jackfruit can be converted into flour. The processing technique followed by Ex-Service Men's Society, Vettilapara is given below

- Removed the spiny region of tender jackfruit.

- Sliced the remaining tender jackfruit in $1 \mathrm{~cm}$ thickness uniform size.

- Soaked it in warm water for 10 minutes

- Tender jackfruit is then kept for freezing at $18^{\circ} \mathrm{C}$ for 10 hours.

- Placed the jackfruit outside for cooling processes.

- Set temperature in the dryer at $50^{\circ} \mathrm{C}$ and then dried the jackfruit for 8 hours.

- Dried and powdered for product development.

\subsection{Physical Property of the Flour}

The tender jackfruit flour (Figure 2) is cream in colour, fine powder has soft texture and it looked similar to wheat flour. It has slight astringency.

\subsection{Estimation of Nutrient Content of the Tender Jackfruit Flour}

The moisture, crude fiber, total ash, crude protein, crude fat, sodium, potassium and calcium was determined using standard procedures ${ }^{5}$ and for determination of 


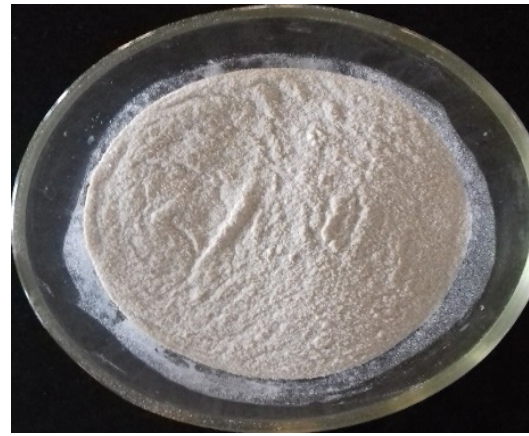

Figure 2. Tender Jackfruit Flour.

nutrient composition, the following parameters were studied and the content of the available carbohydrate was determined by the following equation:

Carbohydrate $(\mathrm{g} / 100 \mathrm{~g}$ sample $)=100-[($ moisture + fat + protein + ash + crude fiber $)$ g/100 g] Energy was determined by following the method described by Pearson, (1976) ${ }^{6}$. Total energy is estimated using the following equation:

Energy $(\mathrm{Kcal} / 100 \mathrm{~g})=\left(\right.$ carbohydrate $\left.{ }^{\star} 4\right)+($ protein $\left.{ }^{\star} 4\right)+\left(\right.$ total fat $\left.{ }^{*} 9\right)$.

\subsection{Survey to identify Breakfast Consumption Pattern of Diabetic Patients in Ernakulam}

\subsubsection{Selection of Area}

Several studies from different parts of Kerala shows the high prevalence of diabetes especially in Ernakulam District. Therefore, the locality selected for the study was Ernakulam District in Kerala. 2.6.2 Selection of Subjects

A total of 60 type 2 diabetic patients were selected equally from urban, rural and coastal areas of Ernakulam District namely Ernakulam, Karukutty and Mulavukad respectively. Patients attending three clinics namely, Ojus in urban area, Neethi in rural area and Mulavukad Health Centre in coastal area were selected as subjects.

\subsubsection{Selection of Tool}

An interview schedule and questionnaire were used to collect the relevant data.

\subsection{Preparation of Breakfast Recipes, Incorporated with Tender Jackfruit Powder}

The present study was designed to develop diabetic breakfast recipes incorporated with tender jackfruit powder. A total of eight recipes most frequently used by the subjects such as, Chapati, Wheat Dosa, Puttu, Idli, Idiyappam, Appam, Porridge and Upma were selected from the survey. The basic ingredient of the recipe was substituted by jackfruit flour by increasing the amount from $25 \%$, to $50 \%, 75 \%$ and $100 \%$ until a good product was obtained. At the time of preparing standard recipes, raw weight of ingredients was measured. Water added for soaking and cooking was also measured. Time for cooking recipes was noted down. Necessary cleaning and washing of raw ingredients were done before cooking.

\subsection{Sensory Evaluation and Nutritive Values of Recipes}

\subsubsection{Sensory Evaluation}

All the developed breakfast recipes (Puttu, Dosa, Appam, Chapatis, Porridge, Idiyappam, Upma, Idlis) were evaluated for sensory quality on the basis of appearance, aroma, taste, texture and overall acceptability using a five point Hedonic scale by a panel of 10 semi trained judges.

\section{Results and Discussion}

\subsection{Proximate Analysis of Tender Jackfruit Flour}

The proximate composition of tender jackfruit flour is given in the table 1 .

Table 1. Proximate Composition of Dried Tender Jackfruit Flour

\begin{tabular}{|c|c|c|}
\hline Sl. No. & Nutritents & Amount $/ \mathbf{1 0 0 g}$ \\
\hline 1 & Carbohydrate & $84.6 \mathrm{~g}$ \\
\hline 2 & Crude fiber & $10 \mathrm{~g}$ \\
\hline 3 & Total protein & $4.99 \mathrm{~g}$ \\
\hline 4 & Total fat & $2.72 \mathrm{~g}$ \\
\hline 5 & Energy & $383 \mathrm{Kcal}$ \\
\hline 6 & Moisture & $5.23 \mathrm{~g}$ \\
\hline 7 & Total ash & $2.43 \mathrm{~g}$ \\
\hline 8 & Sodium & $30 \mathrm{mg}$ \\
\hline 9 & Calcium & $100 \mathrm{mg}$ \\
\hline 10 & Potassium & $860 \mathrm{mg}$ \\
\hline
\end{tabular}

Nutrient analysis of dried tender jackfruit flour (Artocarpus heterophyllus) was done. Hundred grams 
of tender Artocarpus heterophyllus contained 84.63gm carbohydrate, $10 \mathrm{gm}$ fiber, $4.99 \mathrm{gm}$ total protein, $2.27 \mathrm{gm}$ total fat, $382 \mathrm{Kcal}$ energy, $5.23 \mathrm{gm}$ moisture, $2.43 \mathrm{~g}$ total ash, $30 \mathrm{mg}$ sodium, $100 \mathrm{mg}$ calcium and $860 \mathrm{mg}$ potassium.

\subsection{Type of Cereals used in the Breakfast Recipes of Diabetic Subjects}

Type of cereals used in recipes of the diabetic subjects were studied. The figure 3 given below shows the consumption pattern of cereals by 60 diabetic subjects.

In coastal and rural areas mostly rice was consumed as breakfast. Most commonly used cereals were wheat and rice and the percentage consumption among the subjects were $47 \%$ and $44 \%$ respectively. Ragi and oats had low consumption percentage i.e. $4 \%$ and $5 \%$ respectively.

\subsection{Breakfast Incorporation in Tender Jackfruit Flour}

In the incorporation of tender jackfruit flour in eight breakfast recipes (figure 4), 100\% tender jackfruit flour

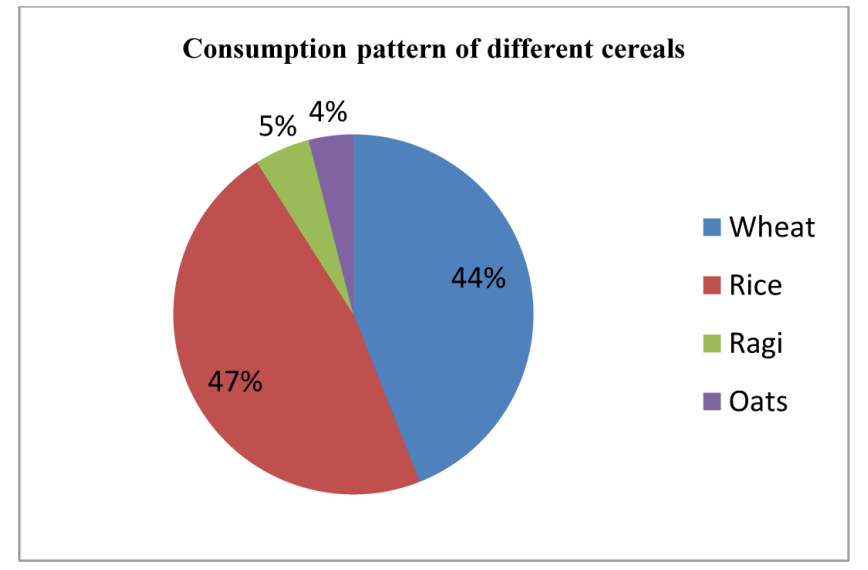

Figure 3. Type of Cereals used in Breakfast Recipe.

was incorporated in Chapati, Puttu and Idiyappam. The idly was made by $50 \%$ tender jackfruit flour. In Appam, Dosa, Porridge and Upma were only 25\% of tender jackfruit flour incorporated. Out of eight breakfast recipes development, appam incorporated with tender jackfruit flour was not well accepted.

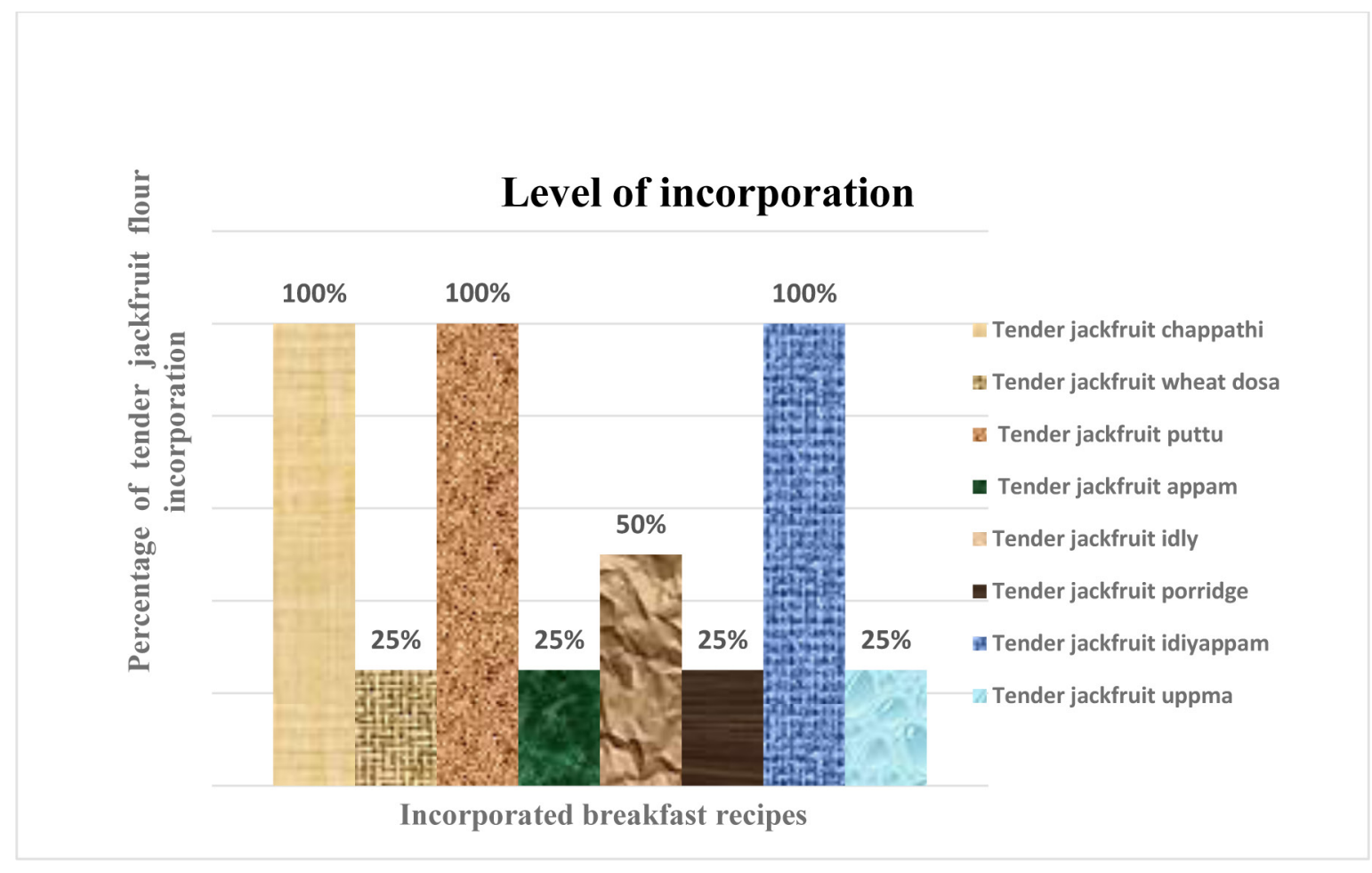

Figure 4. Level of Tender Jackfruit Incorporation in Breakfast Recipes. 


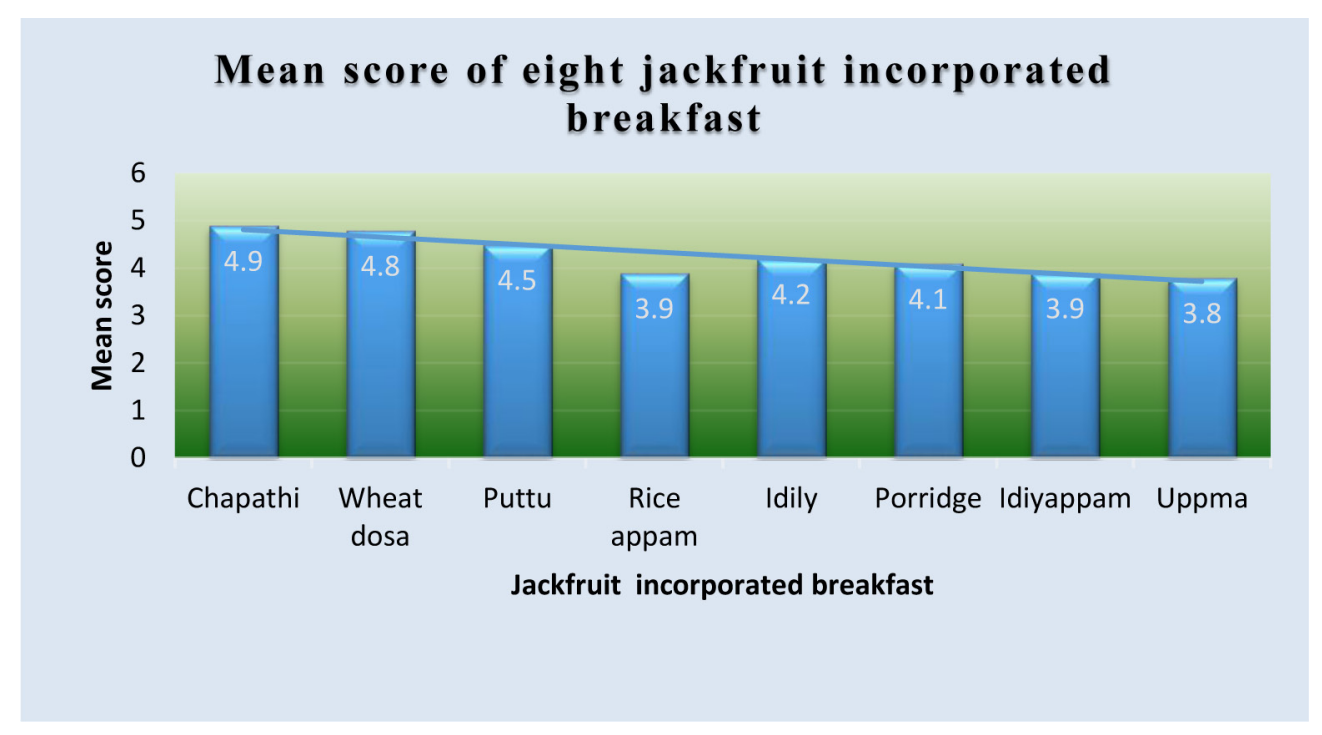

Figure 5. Mean Scores Overall Acceptability of Eight Tender Jackfruit Incorporated Breakfast.

\subsection{Sensory Evaluation of Diabetic Breakfast Recipes Incorporated with Tender Jackfruit Flour}

Tender jackfruit flour was incorporated into a total of eight recipes most frequently used by the selected 60 diabetic subjects. Figure 5 shows the mean acceptability scores of the breakfast items incorporated with tender jackfruit flour.

Chapati had the highest mean score (4.9) and upma had the lowest mean score (3.8). Rice appam had moderate acceptability. Out of eight breakfast recipes developed, Appam prepared with tender jackfruit flour was not well accepted as it was sticky in consistency.

\section{Conclusion}

This study revealed that the tender jackfruit flour is rich in fiber and potassium but low in fat. From the survey, conducted to identify the types of breakfast frequently consumed by diabetic patients in Ernakulum, a total of eight recipes such as Chapati, Wheat Dosa, Puttu, Idli, Idiyappam, Appam, Porridge and Upma were selected. Tender jackfruit flour could completely substitute main ingredients in Chapati, Puttu and Idiyappam. As tender jackfruit flour contains $10 \mathrm{gm}$ fiber per 100gm recipes prepared with it may have low glycemic index. Further studies may be done in this line to find out its effectiveness in controlling blood sugar level.

\section{References}

1. Swami SB, Thakor NJ, haldankar PM, Kalse SB. Jackfruit and its many functional components as related to human health. Comprehensive Reviews in Food Science and Food safety. 2012; 11(6): 565-76. https://doi.org/10.1111/j.1541-4337.2012.00210.x

2. Haq N. Jackfruit (Artocarpus Heterophyllus): Tropical fruits Trees. Edited by Williams JT, Smith RW, Dunsiger Z; Southampton, UK: Southampton Centre for Underutilised Crops, University of Southampton.

3. 3. Hettiaratchi UPK, Ekanayake S, Welihinda W. Do Sri Lankan meals help decrease blood glucose response? Ceylon Medical Journal. 2009; 54: 39-43. https://doi.org/10.4038/cmj.v54i2.793 PMid:19670545

4. Biworo A. Antidiabetic and Antioxidant Activity of Jackfruit (Artocarpus Heterophyllus) Extract. Journal of Medical and Bioengineering. 2015; 4(4): 318-23. https://doi.org/10.12720/jomb.4.4.318-323

5. Raghuramulu N, Madhavan NK, Kalyanasundaram SA. Manual of Laboratory Techniques. Hyderabad, India: National Institute of Nutrition. Indian Council of Medical Research; 2003.

6. Pearson D. Chemical Analysis of Foods. Seventh Edition. London, UK: Church Hill Livingstone; 1976. p. 72-3, 13843, 488-96. 